\title{
GIANT SEBACEOUS HORN ON SCALP: A REVIEW OF LITERATURE
}

\author{
Sushrut M. Fulare ${ }^{1}$, S. D. Deshmukh ${ }^{2}$, R. Sonarker ${ }^{3}$
}

\section{HOW TO CITE THIS ARTICLE:}

Sushrut M. Fulare, S. D. Deshmukh, R. Sonarker. "Giant Sebaceous Horn on Scalp: A Review of Literature". Journal of Evolution of Medical and Dental Sciences 2015; Vol. 4, Issue 38, May 11; Page: 6672-6674, DOI: $10.14260 /$ jemds/2015/965

ABSTRACT: Sebaceous horn or cutaneous horn on the scalp is a rare clinical entity. Cutaneous horns are seen in sun-exposed areas, their association with malignancy makes proper identification of these lesions essential. A case of a giant sebaceous horn of the scalp in an elderly male, which was successfully excised, is reported

KEYWORDS: Cornu cutaneum; cutaneous horn.

INTRODUCTION: Cornu cutaneum (Cutaneous horn) refers to a well- defined cone-shaped lesion with hyper-keratotic features. These are found most frequently on exposed skin,(1) and are typically found on the face and scalp, but may also occur on the penis, eyelids, nose, chest, neck and shoulder. The cutaneous horns are usually benign, however, malignant or premalignant lesions might be associated with it.(2) Because of their malignant potential, the lesions must always be considered for histopathological evaluation.

A 90-years-old male presented with a raised, painless growth over the vertex for more than six years duration. The clinical examination demonstrated a cone-shaped cutaneous horn [Figure - 1]. There was no regional lymphadenopathy. The lesion was excised and it's left open to heal by secondary intention. Specimen was evaluated microscopically. Histopathology of the lesion revealed extreme hyperkeratosis, dyskeratosis, and acanthosis (Figure -2). There was no focus of malignancy, but dermis was chronically inflamed. The follow-up was uneventful without signs of recurrence.

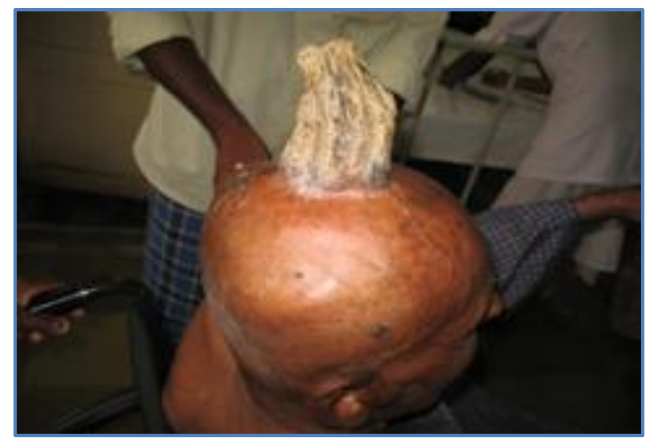

Fig. 1

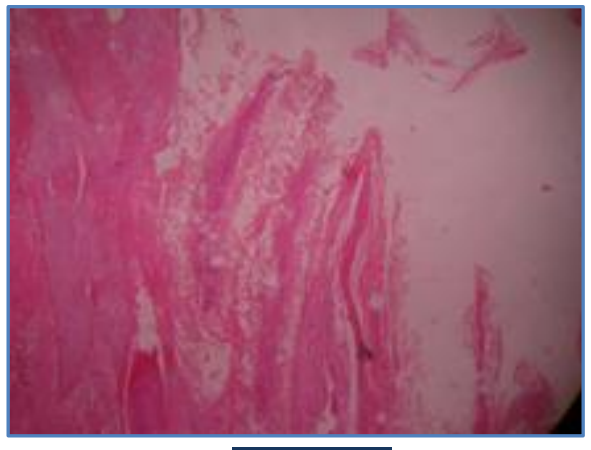

Fig. 2

DISCUSSION WITH REVIEW: A cutaneous horn (Cornu cutaneum) is a protrusion from the skin consisting of cornified material resembling an animal horn in miniature. However, the animal horns are composed of superficial hyperkeratotic epidermis, dermis with centrally positioned bone. No such well-formed bone is observed in the human horns. The earliest well-documented case of cornu cutaneum from London in 1588 is of Mrs. Margaret Gryffith, an elderly Welsh woman. However, earliest observations on cutaneous horns in humans were described by the Everard Home in 1791.[3] 
Various lesions seen at the base of a cutaneous horn include squamous cell carcinoma, actinic keratosis, keratoacanthoma, Bowen's disease, seborrheic keratosis, basal cell carcinoma, hemangioma, keratotic and micaeous pseudopapillomatous balanitis, Kaposi's sarcoma, sebaceous adenoma and Paget's disease of the female breast.(4)

These horns may arise from a variety of benign, premalignant or malignant epidermal lesions. Most commonly, they are single and arise from a seborrheic keratosis lesion. [5] According to a largest study by Yu et al,[2] 61\% of cutaneous horns were derived from benign lesions and 39\% were derived from malignant or premalignant epidermal lesions.

Microscopically, a cutaneous horn shows marked hyperkeratosis, acanthosis, dyskeratosis, papillomatosis and chronic inflammatory infiltration of the adjacent dermis.(1)

Malignant change has been reported in 12 out of the 100 cases. $\left.{ }^{6}\right)$

The important consideration in these cases is not the horn, but the underlying pathology which may be benign (Seborrheic keratosis, viral warts, histiocytoma, inverted follicular keratosis, verrucous epidermal nevus, molluscum contagiosum, etc.), premalignant (Solar keratosis, arsenical keratosis, Bowen's disease) or malignant (Squamous cell carcinoma, rarely, basal cell carcinoma, metastatic renal carcinoma, granular cell tumor, sebaceous carcinoma or Kaposi's sarcoma.[7]

Histopathological examination, specially of the base of the lesion, [1],[8] is necessary to rule out associated malignancy and full excision and reconstruction is the treatment of choice.

The cutaneous horns are predominantly benign lesions; however possibility of malignant potential should always be kept in mind.

\section{REFERENCES:}

1. Lever FW, Schaumburg LG. Histopathology of the skin. $6^{\text {th }}$ Ed, New York: JB Lippincott Co.; 1984.

2. Yu RC, Pryce DW, Macfarlane AW, Stewart TW. A histopathological study of 643 cutaneous horns. Br J Dermatol 1991; 124:449-52.

3. Bondeson J. Everard Home, John Hunter and Cutaneous horns: A historical review. Am J Dermatopathol 2001; 23:362-9.

4. De la Pena Zarzuelo E, Caero Rubias C, Sierra E, Delgado JA, Silmi Moyano A, Resel Estevez L. Cutaneous horn of the penis. Arch Esp. Urol. 2001; 54: 367-8.

5. Thappa DM, Laxmisha C. Cutaneous horn of eyelid. Indian Pediatr 2004; 41:195.

6. Hasan AA, Orter AM, Milan DF. Penile horn: review of literature with 3 case reports, J Uro 1967; 97: 315.

7. Copcu E, Sivrioglu N, Culhaci N. Cutaneous horns: Are these lesions as innocent as they seem to be? World J Surg Oncol 2004; 2:18.

8. Gould JW, Brodell RT. Giant cutaneous horn associated with verruca vulgaris. Cutis 1999; 64:111-2. 


\section{AUTHORS:}

1. Sushrut M. Fulare

2. S. D. Deshmukh

3. R. Sonarker

\section{PARTICULARS OF CONTRIBUTORS:}

1. Associate Professor, Department of Surgery, NKP Salve Institute of Medical Sciences, Nagpur.

2. Associate Professor, Department of Surgery, NKP Salve Institute of Medical Sciences, Nagpur.

3. Assistant Professor, Department of Surgery, NKP Salve Institute of Medical Sciences, Nagpur.

\section{FINANCIAL OR OTHER} COMPETING INTERESTS: None

\section{NAME ADDRESS EMAIL ID OF THE CORRESPONDING AUTHOR:}

Dr. Sushrut M. Fulare, Associate Professor, Department of Surgery, Plot No. 236, Surendra Nagar, Nagpur-440015, Maharashtra, India.

E-mail: drsmfulare@gmail.com

Date of Submission: 20/03/2015. Date of Peer Review: 21/03/2015. Date of Acceptance: 01/05/2015. Date of Publishing: 09/05/2015. 